\title{
Does a higher number of siblings protect against the development of allergy and asthma? A review
}

\section{W Karmaus, C Botezan}

See end of article for authors' affiliations

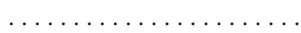

Correspondence to: Dr W Karmaus, Department of Epidemiology, Michigan State University, $4660 \mathrm{~S}$ Hagadorn Road, Suite 600 , East Lansing, $\mathrm{MI}$ 48823, USA:

karmaus@msu.edu

Accepted for publication 24 July 2001

\begin{abstract}
Study objective: To review the "protective" effects of having a higher number of siblings for the risk of atopic eczema, asthma wheezing, hay fever, and allergic sensitisation.

Method: Review of the literature (Medline since 1965 and references).

Main results: 53 different studies were identified. For eczema, 9 of 11 studies reported an inverse relation with number of siblings; for asthma and wheezing, 21 of 31 reported the inverse association; for hay fever, all 17 studies showed the effect; for allergic sensitisation or immunoglobulin $\mathrm{E}$ reactivity 14 of 16 studies supported the "protective" effect of a higher number of siblings. The studies emphasise a "theory" that is based exclusively on epidemiological associations.

Conclusions: Research has not yet answered the question of which causal factors explain the sibling effect. Causal factors must meet two criteria; they must vary with sibship size and they must protect against atopic manifestations. The prevailing "hygiene hypothesis" failed to explain the findings adequately. Alternative explanations include in utero programming or endocrine explanatory models. The epidemiology research into siblings and atopic disorders has entered an intellectually challenging phase. Possessing sufficient knowledge about the causal factors might prevent at least $30 \%$ of all cases of asthma, eczema, and hay fever.
\end{abstract}

R ecent studies show that sibship size is a protective factor for allergy in both children and adults. This phenomenon, described in the literature as the "sibling effect," was first described by Golding and Peters in a cross sectional analysis of a national cohort known as the British Birth Survey. ${ }^{1}$ The study aimed to assess health and behaviour in children in Great Britain, as well as epidemiological associations with risk factors such as household conditions, social class, smoking, etc, and attempted to contact the whole population born in one week in $1970(n=16567)$ at around their fifth birthday. Outcomes were measured by asking the mother if the child had ever had asthma, wheezing, eczema, or hay fever, and the prevalence was compared for groups with different risk factors. For asthma or wheezing, there was no association with the number of other children in the family, but for eczema and hay fever, a significant decrease in risk with an increasing number of siblings was detected. This association was later found consistently in many other studies, not only for eczema and hay fever, but also for asthma, wheezing, and sensitisation to allergens measured either by skin prick test (SPT) or by specific blood immunoglobulin E reactivity ( $\mathrm{IgE}$ ).

We consider different clinical manifestations, namely bronchial asthma, atopic eczema, hay fever, and clinical markers, that is, SPT positivity and IgE reactivity, as different expressions of the same biological pathogenesis: atopy. The term atopy describes a syndrome, which is immunologically characterised by the production of specific IgE antibodies after antigen (allergen) stimulation. To identify this process, increased IgE levels or SPT sensitisations are determined. It is assumed that after repeated allergen exposures, the syndrome becomes clinically manifest, for example, as food allergy, atopic eczema, bronchial asthma, and hay fever. ${ }^{23}$

Objectives are to review the literature on the sibling effect in atopic eczema, asthma, hay fever, and allergic sensitisation measured by SPT or IgE and to discuss factors that might contribute to the phenomenon.

\section{REVIEW METHODS}

The review started with a pre-existing reference library on the subject, completed with a systematic Medline search (1965-
2000) for articles that reported their results on atopic disorders by number of siblings (key words: asthma, hay fever, eczema, atopic dermatitis, atopy associated with siblings, family size).

There was some ambiguity as to what the sibling effect represented. It was defined as the birth order, the number of siblings, or the family size, ${ }^{4}$ the number of older siblings, ${ }^{5-10}$ or even the number of brothers. ${ }^{511}$ Also, the number of younger siblings was taken into consideration (younger siblings $=$ birth order -1 ). The majority of the publications provided estimates of relative risks (risk or odds ratios) for three or more siblings. Whenever feasible, we provide results showing adjusted or unadjusted risk or odds ratios for having an atopic manifestation for three or more versus no siblings. There are a few cases for which we only identify percentages or relative risk estimates for 2 , or 4 , or 5 and more. If only prevalences for strata with different sibling sizes were provided, the unadjusted odds ratio for three or more siblings versus no sibling was calculated, along with the corresponding 95\% confidence intervals. Risk ratios and odds ratios and their 95\% confidence intervals were illustrated graphically. We acknowledge that there might be some minor numerical problems comparing odds and risk ratios. The differences, however, are small because the manifestations represent rare diseases. We did not exclude any publication. However, if a study could not be included in the graphical presentations, because the outcome did not fit in one of the four categories (hay fever, asthma, eczema, or sensitisation), the effect was measured as family size, or odds ratios were not reported and could not be calculated, the results were summarised in a separate table. If one sample was used in several publications, we included results from only one article. To summarise the studies for the different manifestations, we calculated an average odds ratio weighted for the sample size.

Abbreviations: SPT, skin prick test; lgE, immunoglobulin E 
Table 1 Studies showing a relation between family size and atopic disease that could not be included in figures 1 to 4 (no frequencies/odds ratio reported or outcome did not fit in one of the four categories)

\begin{tabular}{|c|c|c|c|}
\hline Author and year & Outcome measured & Findings & Measure of association \\
\hline $\begin{array}{l}\text { Bråbäck et al, } \\
1995^{45} \\
\mathrm{n}=2232\end{array}$ & SPT & $\begin{array}{l}\text { The number of siblings and domestic } \\
\text { crowding were inversely related to } \\
\text { sensitisation }\end{array}$ & $\begin{array}{l}O R=0.58(0.43 \text { to } 0.77) \text { for number of persons } \\
\text { per room }\end{array}$ \\
\hline $\begin{array}{l}\text { Burr et al, } 1997^{47} \\
n=437 \text { for SPT } \\
n=338 \text { for } \lg E\end{array}$ & $\begin{array}{l}\text { SPT, IgE, wheezing, eczema, hay } \\
\text { fever (children with family history of } \\
\text { atopy) }\end{array}$ & $\begin{array}{l}\text { There was a non-significant negative } \\
\text { association of SPT and lgE with number of } \\
\text { older siblings }\end{array}$ & $\begin{array}{l}p=0.13 \text { for } S P T \\
p=0.12 \text { for } \lg E\end{array}$ \\
\hline $\begin{array}{l}\text { Mattes et al, } 1998^{\circ} \\
\mathrm{n}=3165\end{array}$ & $\begin{array}{l}\text { Atopic disorder (asthma, hay fever, or } \\
\text { eczema) }\end{array}$ & $\begin{array}{l}\text { Inverse relation between number of older } \\
\text { siblings and atopic disease }\end{array}$ & $\begin{array}{l}\mathrm{OR}=0.4(0.19 \text { to } 0.83) \text { for }+3 \text { older siblings } \\
\mathrm{OR}=1.14(0.70 \text { to } 1.85) \text { for }+3 \text { younger } \\
\text { siblings }\end{array}$ \\
\hline $\begin{array}{l}\text { Strachan et al, } \\
1997^{5} \\
n=11042\end{array}$ & $\begin{array}{l}\text { Inhalant allergy (cat, pollen, or dust) } \\
\text { and non-inhalant allergy (insect bites } \\
\text { or something else) }\end{array}$ & $\begin{array}{l}\text { Inhalant allergy was inversely related with } \\
\text { the number of siblings }\end{array}$ & $\begin{array}{l}\mathrm{OR}=0.76(0.59 \text { to } 0.97) \\
\text { (not adjusted) }\end{array}$ \\
\hline Tariq et al, $1998^{53}$ & $\begin{array}{l}\text { Atopic disorder (asthma, eczema, or } \\
\text { hay fever) }\end{array}$ & $\begin{array}{l}\text { Weak inverse relation of number of siblings } \\
\text { with atopic illness and SPT }\end{array}$ & $P R=0.41$ for atopic illness (not significant) \\
\hline $\begin{array}{l}n=1215 \text { for atopic } \\
\text { illness } \\
n=981 \text { for SPT }\end{array}$ & SPT & & $\begin{array}{l}\mathrm{PR}=0.61 \text { for SPT (not significant), } 4 \text { siblings } v \\
\text { no }\end{array}$ \\
\hline $\begin{array}{l}\text { Taylor et al, } 1983^{19} \\
n=12743\end{array}$ & $\begin{array}{l}\text { Eczema, hay fever, wheezing, and } \\
\text { asthma }\end{array}$ & $\begin{array}{l}\text { Having older siblings was inversely } \\
\text { associated with hay fever, no associations } \\
\text { with eczema of asthma }\end{array}$ & $\begin{array}{l}\mathrm{PR}=0.56 \text { of having older siblings } v \text { no older } \\
\text { siblings for hay fever (no } \mathrm{Cl} \text { or } \mathrm{p} \text { value } \\
\text { provided) }\end{array}$ \\
\hline $\begin{array}{l}\text { Weitzman et al, } \\
1990^{41} \\
n=15224\end{array}$ & Asthma and use of asthma medication & $\begin{array}{l}\text { Asthma was positively associated with } \\
\text { having a large family size (more than } 6 \\
\text { members) }\end{array}$ & $\begin{array}{l}\mathrm{OR}=1.9(1.2 \text { to } 3.1) \text { for } 6 \text { or more family } \\
\text { members } v \text { less than six }\end{array}$ \\
\hline Attena et al, $1999^{28}$ & Medical diagnosis of asthma & $\begin{array}{l}\text { Firstborn had } 1.89 \text { times more asthma than } \\
\text { other siblings }\end{array}$ & $O R=1.89$ for firstborn $(p=0.048)$ \\
\hline $\begin{array}{l}\text { Lewis et al, } 1998 \\
n=7162^{17}\end{array}$ & Eczema & $\begin{array}{l}\text { Significant trend of increased risk of eczema } \\
\text { at the age of } 16 \text { in firstborn compared with } \\
\text { subsequent children. }\end{array}$ & $\begin{array}{l}\text { Graphical presentation: } O R \simeq 0.92 \text { for the third } \\
\text { child, and } O R \simeq 0.78 \text { for the fourth child } \\
\text { compared with the first. }\end{array}$ \\
\hline $\begin{array}{l}\text { Moyes et al, } 1995 \\
\mathrm{n}=577^{24}\end{array}$ & Cough and wheeze & $\begin{array}{l}\text { Cough and wheeze was more common in } \\
\text { primary children }\end{array}$ & $\begin{array}{l}\text { Cough: primary children } O R=1.3(1 \text { to } 1.7) \text {, } \\
\text { wheeze: } O R=1.5(1 \text { to } 2.3)\end{array}$ \\
\hline
\end{tabular}

\section{RESULTS}

A total of 53 studies dealing with atopic disorders and/or sensitisation and number of siblings were identified. The associations between atopic manifestations and siblings were summarised in figures 1 to 4 and in table 1 .

\section{Eczema}

The outcomes measured were history of eczema, eczema in the first year of life, parental report of doctor's diagnosis of eczema, and specialist diagnosis of atopic dermatitis. Eleven of the reviewed studies reported results on eczema and family size (fig 1, table 1). Ten reported an inverse association with number of siblings, ${ }^{12-18}$ of which five were statistically significant. One found a significant inverse association for older siblings only, while for younger siblings there was no association. ${ }^{7}$ Lewis et al reported an inverse trend with an increasing number of siblings (table 1 ). ${ }^{17}$ Two studies reported no association between eczema and the number of siblings (table 1 and fig 1 )..$^{15}{ }^{19}$ Of the 11 studies, one is a case series that included siblings, three are cross sectional, and seven are cohort studies. The weighted average odds ratio for having eczema is 0.66 when having three or more siblings.

\section{Asthma or wheezing}

Findings were reported for the following outcomes: if the child had ever had wheezing or whistling in the chest in the past 12 months, or had ever had asthma or asthma in the past 12 months, or a doctor's diagnosis of asthma. Although the negative association between asthma or wheezing and sibling size is less consistent (fig 2), from a number of 31 studies reporting results on asthma or wheezing in relation to the number of siblings, 22 studies found a negative association, with odds ratios ranging from 0.20 to $0.84 .^{1013161820-2425-37}$ The association reported by Wickens is based on two or more siblings. ${ }^{31}$ For Italian recruits, Attena et al reported that the firstborn child had a higher prevalence of asthma (table 1); Moyes reported the same for children in New Zealand. ${ }^{24}{ }^{28}$ In 18 of the reports, the relation was statistically significant. Six studies failed to find any association to family size, including some publications that investigated an identical sample. ${ }^{12} 1719233839$ Only one study found a positive association with having three or more siblings to asthma or wheezing. ${ }^{40}$ Weitzman et al investigated the family size, not the number of siblings, and reported a positive association with asthma and the use of asthma medication (table 1 ). ${ }^{41}$ Of the 31 studies, three are casecontrol, 21 are cross sectional, and seven are cohort studies. The average odds ratio weighted for sample size was dominated by a Swedish study of military recruits $(n=148324)$. Including this sample, the weighted odds ratio was 0.93 , but when this study was excluded the weighted odds ratio became 0.72 .

One report included results of three surveys with the same questions on respiratory symptoms repeated at three different times: 1977, 1986, and $1994 .^{30}$ Each survey included schoolchildren aged 5 to 11 from the identical geographical area in the United Kingdom. Although there was a significant negative association of asthma with family size when data from all surveys are pooled, the results show that the odds ratios of asthma or wheezing by family size changed over time. In the 1977 survey, there was no association; in 1986 there was a nonsignificant, weak association, while in the 1994 survey the association became stronger and was statistically significant.

\section{Hay fever}

The outcomes included history of hay fever, current hay fever, hay fever in the past 12 months, and doctor's diagnosis of hay fever. The age when outcomes were measured varied between 7 and 44 years.

Of the 17 studies that reported a result on hay fever in relation to siblings, all found a significant negative relation (fig 3 , table 1). The odds ratios vary between 0.20 and 0.65 for three or more siblings versus no siblings. ${ }^{1812-1926293337-394243}$ Lewis et al reported associations for four children and more. ${ }^{17}{ }^{23}$ Taylor et al found a prevalence ratio of $6 \%$ for the oldest and of $3.4 \%$ for children with older siblings (table 1), but did not provide the actual number of siblings. ${ }^{19}$ Some of the studies reported 


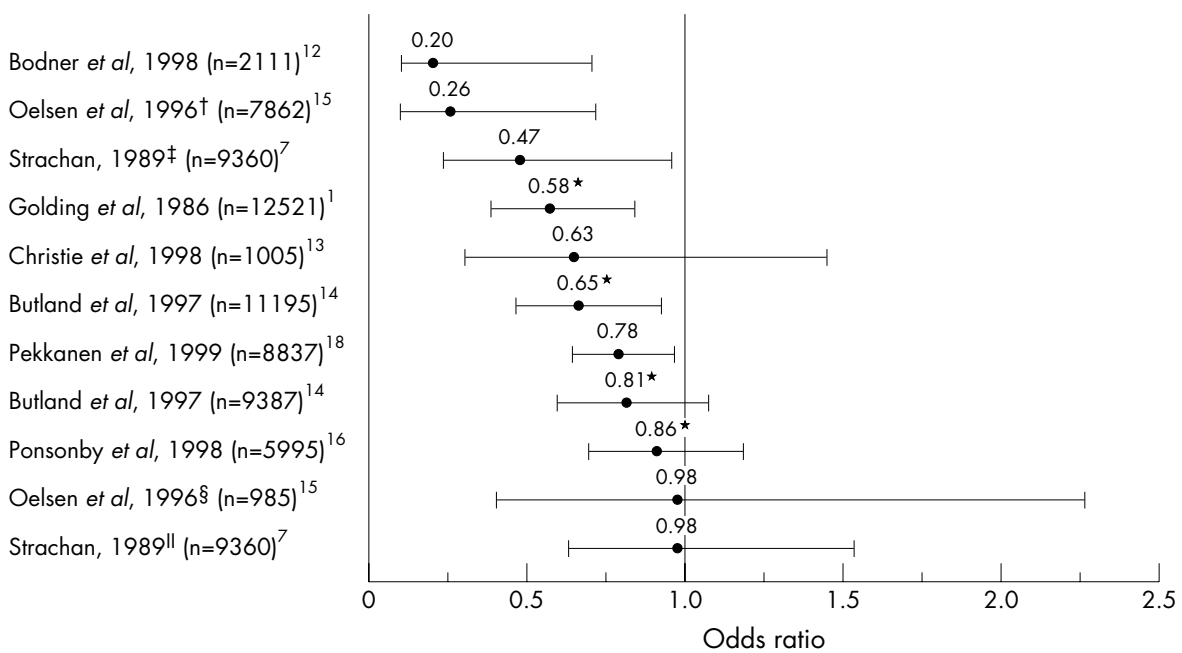

Figure 1 Eczema and number of siblings: three or more versus none. Odds ratios and $95 \%$ confidence intervals for large number of siblings (in most studies: three and more) and eczema in different studies. Odds ratios are adjusted for other risk factors, except for those marked with an asterisk. †Specialist diagnosis of atopic dermatitis, older siblings only; łolder siblings only; §parent's report of diagnosis of atopic dermatitis, older siblings only; Iyounger siblings only.

the results separately for older and younger siblings. ${ }^{8}{ }^{42}$ In this case, the effect of older siblings was stronger than the effect of younger siblings (fig 3).

Of the 17 studies, eight had a cross sectional design, and nine a cohort design. Again, the weighted average was influenced by the large sample size of the Swedish study. Therefore, the weighted odds ratio including this study was 0.56 . The odds ratio without the Swedish sample was 0.44 .

\section{SPT/IgE reactivity}

In all of the reviewed studies, sensitisation was defined as a positive SPT reaction or a positive specific IgE serum antibody to any of the allergens tested. Although the definitions of positivity vary, sensitisation to specific allergens was found to be negatively associated with three or more siblings in 14 of 16 studies (fig 4, table 1). ${ }^{611262944-52}$ Of these, 10 reported statistically significant associations. Only two studies found a positive association, which was unadjusted for possible confounders. ${ }^{40}{ }^{52}$ Bråbäck et al reported a significant inverse association of domestic crowding with sensitisation (table 1); Burr et al reported an insignificant negative association of number of older siblings with sensitisation. ${ }^{45} 47$

Three of the 14 studies that showed a negative relation reported their results separately for younger and older

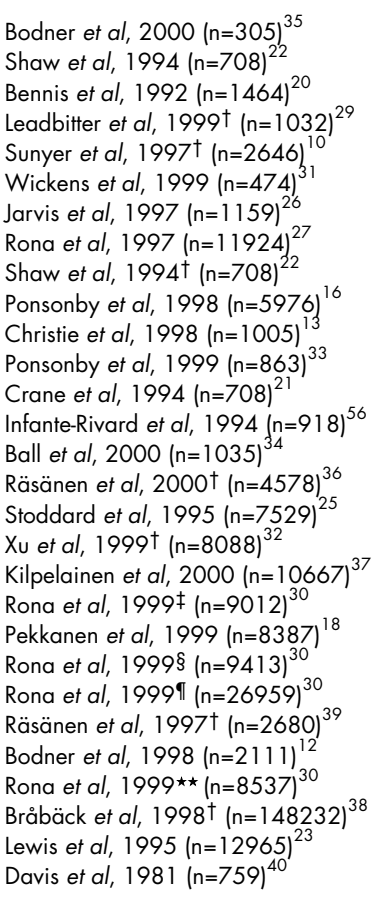

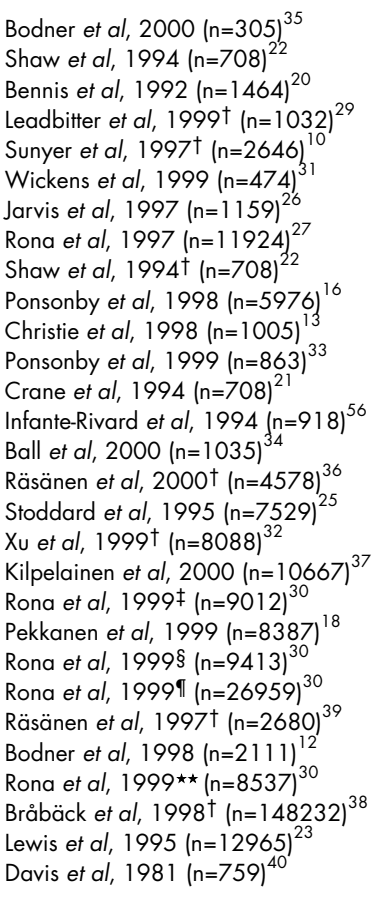

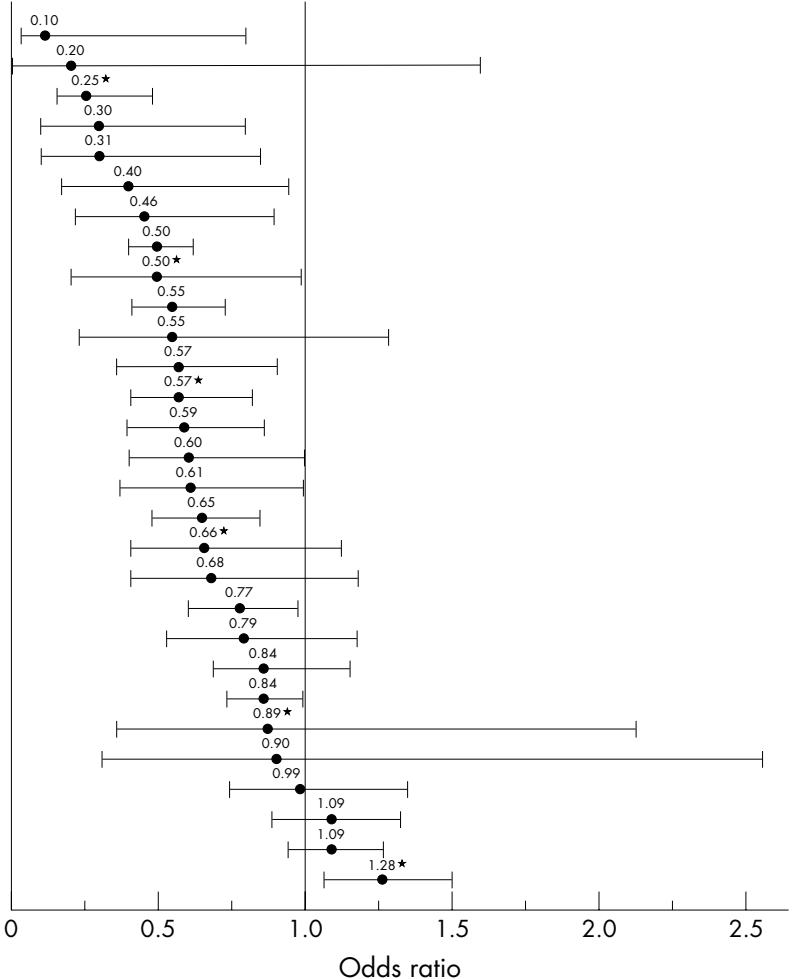

Odds ratio

Figure 2 Asthma or wheezing and number of siblings: three or more versus none. Odds ratios and $95 \%$ confidence intervals for large number of siblings (in most studies: three and more) and asthma or wheezing in different studies. Odds ratios are adjusted for other risk factors, except for those marked with an asterisk. †Older siblings only; ¥1994 survey; §1986 survey; Iall surveys; ** 1977 survey. 


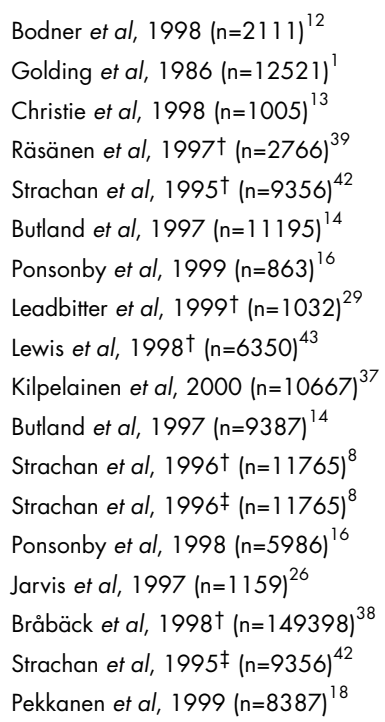

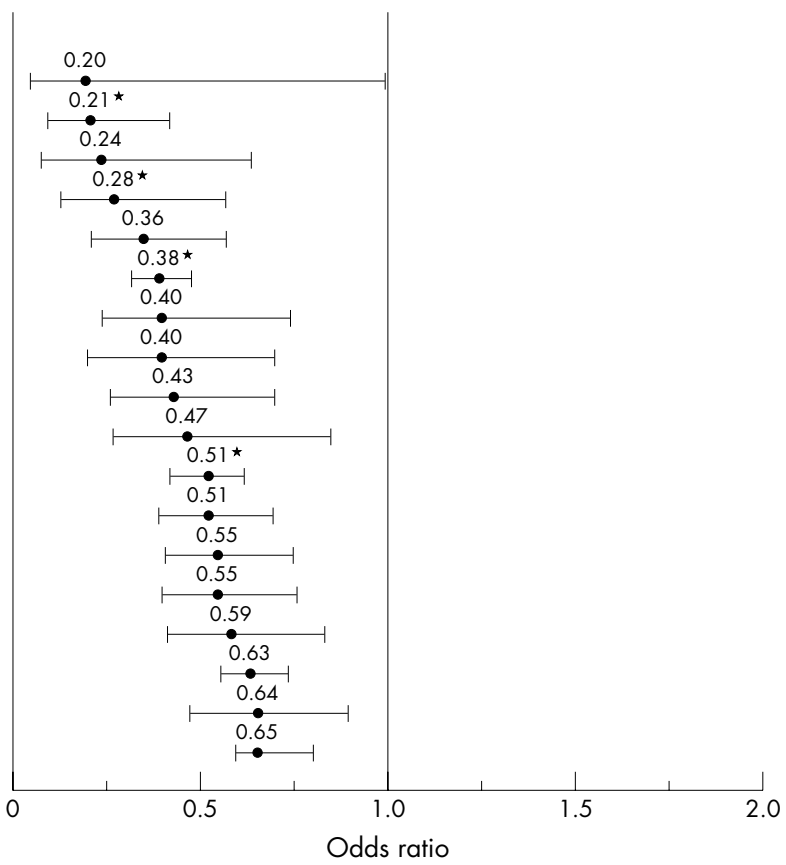

Odds ratio

Figure 3 Hay fever and number of siblings: three or more versus none. Odds ratios and $95 \%$ confidence intervals for large number of siblings (in most studies: three and more) and hay fever in different studies. Odds ratios are adjusted for other risk factors, except for those marked with an asterisk. †Older siblings only; łyounger siblings only.

siblings. Although both younger and older siblings seemed to protect against sensitisation, in two of the three studies the association was significant only for older siblings. ${ }^{11} 480$ All three showed a stronger effect for older siblings. Svanes et al, however, did not identify a significant association with older or younger siblings after accounting for total number of siblings. ${ }^{11}$

Of the 16 studies, 11 were cross sectional, four were cohort studies, and one had a case-control design. The weighted average odds ratio for having SPT/IgE reactivity is 0.62 when having three or more siblings.

Table 1 shows the findings of the studies that could not be described in figures 1 to 4 . Mattes et al reported an inverse association between number of older siblings and atopy in general (asthma, hay fever, eczema). ${ }^{9}$ Strachan et al found an inverse relation between number of siblings and inhalant allergy. ${ }^{5}$ Tariq et al showed a weak inverse relation of the number of siblings with atopic illness and SPT. ${ }^{53}$

\section{DISCUSSION}

From 53 studies reviewed, 48 found a negative association between number of siblings and all or some of the outcomes studied, and only three reported a positive relation. The effect is more consistent for hay fever and sensitisation than for asthma or wheezing and eczema. Most studies were from Europe, some were from New Zealand, and only a few from the US.

The studies present a variety of approaches and different types of epidemiological studies (cross sectional, case-control, and cohort). With regard to the sibling effect, different designs

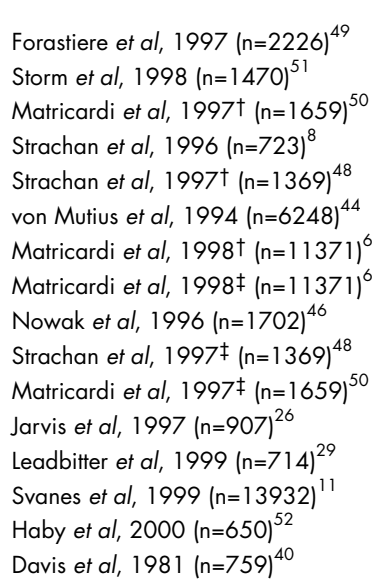

Forastiere et al, $1997(\mathrm{n}=2226)^{49}$ Storm et al, $1998(n=1470)^{5}$ Matricardi et al, $1997+(n=1659)^{50}$ Strachan et al, $1997^{\dagger}(n=1369)^{48}$ Matricardi et al, $1998^{\dagger}(n=11371)^{6}$ Matricardi et al, 1998 $\$(n=11371)^{6}$ Nowak et al, $1996(n=1702)^{46}$ Strachan et al, 1997 $(n=1369)^{48}$ Matricardi et al, $1997 \ddagger(n=1659)^{50}$ Jarvis et al, $1997(\mathrm{n}=907)^{26}$ Leadbitter et al, $1999(\mathrm{n}=714)^{29}$ Haby et al, $2000(n=650)^{52}$ Davis et al, $1981(n=759)^{40}$

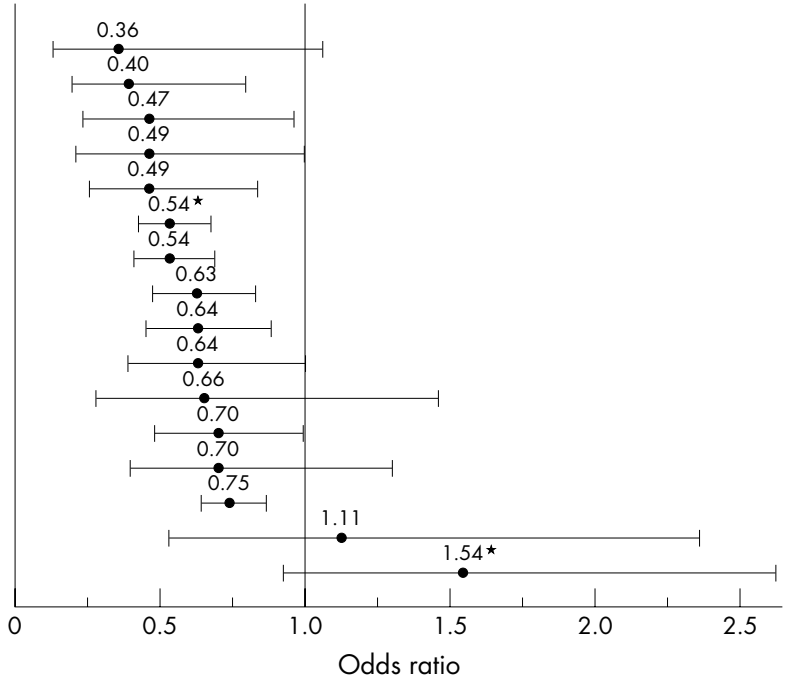

Odds ratio

Figure $4 \mathrm{SPT} / \mathrm{lgE}$ reactivity and number of siblings: three or more versus none. Odds ratios and $95 \%$ confidence intervals for large number of siblings (in most studies: three and more) and SPT or lgE reactivity to at least one allergen in different studies. Odds ratios are adjusted for other risk factors, except for those marked with an asterisk. †Older siblings only; łyounger siblings only. 


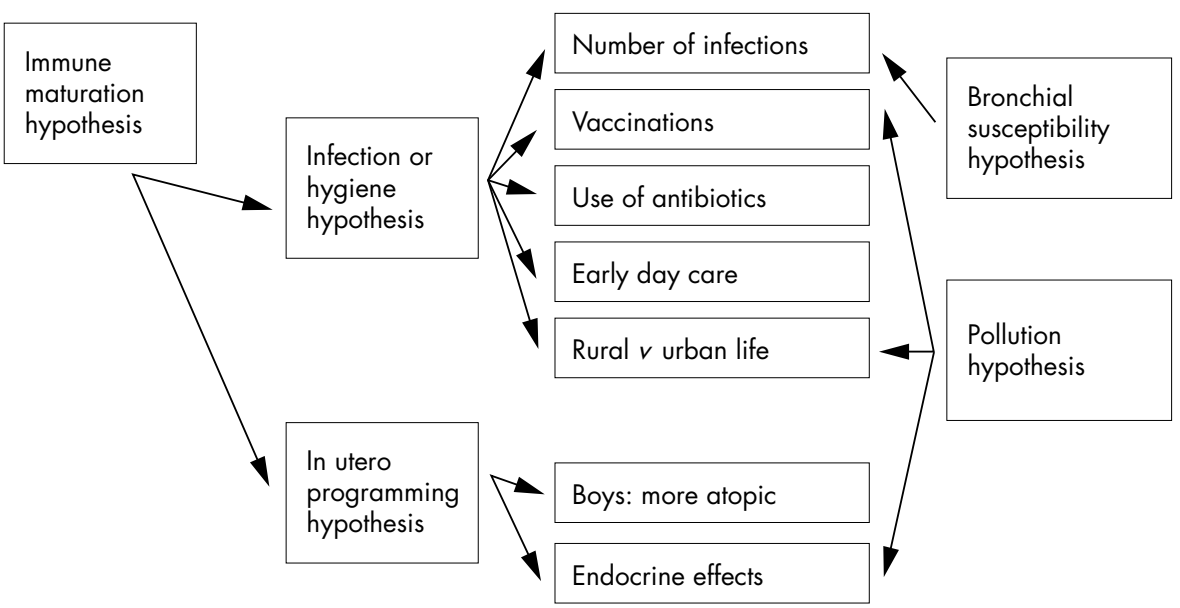

Figure 5 Interrelation of conflicting concepts and hypotheses that may explain the sibling effect.

ain the sibling effect.

concepts/hypotheses - . . .

did not reveal different results. We focused on one common predictor, the number of siblings that has gained enormous attraction for aetiological research. The different atopic manifestations were ostensibly characterised by a common pattern of association to the number of siblings.

The pattern is more consistent for hay fever and sensitisation than for asthma or wheezing and eczema. A probable reason for the more consistent pattern is that hay fever has specific symptoms and is perhaps less likely to be misdiagnosed. Also sensitisation is measured by standard procedures and characterised by low longitudinal variability in childhood. ${ }^{54}$ Regarding asthma, variable and unspecific respiratory signs not related to asthma or atopy are frequent in children and complicate clinical diagnoses. ${ }^{2}$ Wheezing, its most important symptom, can also be associated with respiratory infections and environmental tobacco smoke exposure and is not solely a sign of atopic asthma. ${ }^{55}$ Ambiguities over the definition of asthma, especially during infancy and early childhood, thus make associations more prone to misclassification. This might explain why some studies found a sibling effect for hay fever but failed to find the same effect for asthma. ${ }^{13} 38$ However, in a recent study, the sibling effect on asthma was not weaker in children with transient asthma. ${ }^{56}$ Additionally, it is likely that mechanisms involved are atopic and that the weaker effect for asthma is because not all asthma cases occur through this mechanism.

The sibling effect was approached with different indicators (family size, birth order, number of siblings). Birth order equalled the number of older siblings plus one. Only a few studies did not provide estimates of the frequency of atopic manifestation for the number of siblings, and therefore could not be included in the graphical presentation (figs 1-4). The results of these studies (table 1), however, do not deviate from the ones included. Only the study of Weitzmann et al for example, focused on the family size, not the number of siblings. ${ }^{41}$ Additionally, when detailed results by number of siblings were provided, most studies indicate a dose-response relation between the number of siblings and atopy. However, we did not perform any meta-analysis, and therefore we did not analyse the overall dose-response relation.

Six of the seven analyses that investigated for different manifestations the effect of both older and younger, and that provided a relative risk estimate, showed a stronger protective effect for having older siblings.

Surprisingly, 31 of the 53 different studies did not include parental history of eczema, asthma, of hay fever, or maternal age as confounders. However, the studies that adjusted the sibling effect for maternal age and/or maternal atopy did not show different results.

A comparison by Rona et al suggested that the sibling effect for asthma attacks was stronger for more recent cohorts. ${ }^{30}$ Compared with 1977, the prevalence of asthma attacks increased from $9.5 \%$ to $13.5 \%$ in 1994 in children with three or more siblings, but from $10.4 \%$ to $17.3 \%$ in single children (fig 2).

A methodological limitation of all findings is attributable to the fact that the analyses are based on comparisons between families. Professionals and laymen claim that atopic reactions cluster in families. Thus, there is a need to analyse simultaneously within family associations, including all siblings and between family effects. If the sibling effect characterises families or lifestyles, we would expect then that "clusters" of children with atopic manifestations would occur less frequently in families with a higher number of siblings. However, if the sibling effect characterises children, we might detect an equal proportion of families with atopic children, with only the younger children being protected.

Although the magnitude and consistency of the sibling effect are remarkable, the process behind this association is largely unknown. We have to deal with findings and a "theory" that is based exclusively on epidemiological associations. If we were to identify the factors that cause the phenomenon of the sibling effect and if these factors were applied to children with a low number of siblings, then the cases in this group might be diminished by $28 \%$ for asthma (attributable proportion based on the weighted odds ratio, not including the Swedish study), 34\% for eczema, 56\% for hay fever, and 38\% for SPT/IgE reactivity.

Several biological explanations have emerged in recent years. One major school of thought is focused on the immune maturation (protective effects or risk of infections/vaccination/ hygiene, antibiotic use). Other explanations focus on in utero programming and endocrine effects (fig 5).

On a cellular basis, the development of $\mathrm{T}$ lymphocyte responsiveness to allergens is a prerequisite for allergic (atopic) reactivity. The T-helper 2 cells (Th2 cells) determine the level of involvement of the mast cells and eosinophils in the host response. Through secretion of the cytokine IL4, Th2 cells regulate the synthesis of IgE antibodies, and through the cytokine IL5, they also control eosinophil differentiation and activation. ${ }^{57}$ However, if significant other cytokines, for example, interferon $\gamma$ (IFN $\gamma$ ), which counteract the effects of IL4 are 
present, the reaction is assumed to be pushed toward a Thl phenotype, which causes the secretion of IgG antibodies and the removal of the allergen. ${ }^{58}$ The Thl phenotype is characteristic for non-atopics.

The immune maturation approach conceptualises atopic disorders as a failure of the immune deviation that should normally select for Thl memory cells during allergen driven immune response in early life. ${ }^{59}$ It has been established that the fetal immune response is constitutively skewed away from the Thl phenotype. This apparently represents an evolutionary adaptation designed to protect the rejection of the maternal unit. This Th2 skew seems to be maintained postnatally in atopic children. ${ }^{59} 60$

Within this framework of immune maturation, the hygiene hypothesis ${ }^{7}$ envisages that the increasing efficiency of hygiene in the (Western) developed world, coupled with lower family sizes, has reduced the contact with infections in early life (fig $5)$; such contact that would otherwise have promoted an immune deviation towards the Thl pattern. ${ }^{44-63}$ Others named this assumption the "Westernisation" hypothesis. ${ }^{64-66}$ Within the hygiene hypothesis, different approaches specified exposures differently: history and marker infections, vaccination, antibiotic use, early day care attendance, and a childhood farm environment (fig 5). In line with these explanations are findings indicating that children with an anthroposophic lifestyle had less atopy. In this lifestyle, founded by Rudolf Steiner in the early 20 th century, children are characterised by fewer mumps, measles, and rubella (MMR) vaccinations, a higher prevalence of measles history, a lower use of antibiotics, and a higher consumption of fermented vegetables that affect the intestinal flora. ${ }^{67}$

\section{History and markers of infection}

In children, measles infections seem to be protective against later development of atopy (Guinea-Bissau, allergic sensitisation: $\mathrm{OR}=0.2,{ }^{68}$ United Kingdom, asthma: $\mathrm{OR}=0.5,{ }^{12} \mathrm{New}$ Zealand: $\left.0.48,{ }^{31}\right)$. In a Swedish study with children from Steiner schools, no association was detected for measles, but there was a protective effect associated with no MMR vaccination. ${ }^{67}$ Also Lewis et al reported no main effects for measles infection or measles vaccination in England. ${ }^{43}$ However, the associations were evidently more complicated when taking into account the number of siblings. The authors reported that the combined effect of measles infection and/or measles vaccination in childhood and having an older sibling reduced the risk of hay fever in children.

A study from New Zealand indicated that children who received no diphtheria/pertussis/ tetanus (DPT) vaccination $(n=23)$ had not had any reported asthma episodes, but about $23 \%$ of the other children $(n=1242)$ had. ${ }^{69}$ This finding is supported by an English study that found an increased relative risk for atopic disease in children who received immunisation with whole cell pertussis vaccine. ${ }^{70}$ In another study from New Zealand and in a British study, however, pertussis infection was not associated significantly with wheezing or asthma in children. ${ }^{71}{ }^{72}$

Tuberculin positivity at age 6 and 12 was associated with a reduction of atopic manifestations and IgE levels in Japanese children at age $12 .{ }^{73}$ The study also showed an inverse association between delayed hypersensivity to tuberculin and total IgE. Also, in African children, BCG vaccination given in infancy showed a reduced risk for positive SPT. ${ }^{74}$ A Swedish and a Norwegian study, however, did not find associations between positive tuberculin tests or BCG vaccination and the prevalence of atopy, respectively the IgE level. ${ }^{75}{ }^{76}$ An aggregative study, based on a comparison of tuberculosis rates of countries in Europe, the USA, Canada, and Australia with the prevalence of wheezing in ISAAC study centres, reported an inverse relation. An increase in tuberculosis notification of 25 per 100000 was associated with a decrease in the lifetime prevalence of wheezing of $4.7 \% .^{77}$

\section{Key points}

- The sibling effect describes a phenomenon that is based exclusively on empirical findings. No comprehensive biological explanation has yet emerged.

- For eczema, 10 of 11 studies reported an inverse association with number of siblings, 22 of 31 studies on asthma, all 17 studies on hay fever, and 14 of 16 studies on allergic sensitisation.

- If we identify and apply the factors causing the sibling effect we could prevent at least $30 \%$ of atopic disorders.

- The hygiene hypothesis failed to explain the findings adequately, or at least did not yet integrate essential and integrating explanations.

- It is time to consider alternative explanations such as in utero programming or endocrine effects.

Matricardi et al found that exposure to infections, particularly to those spread by the faecal-oral route (hepatitis A and Toxoplasma gondii), were significantly less frequent in atopic cases in Italian male cadets. ${ }^{78}$ Bodner et al could not support these findings. Seropositivity for hepatitis A, Heliobacter pylori, and Toxoplasma gondii was not related to adult wheezing and atopy. ${ }^{35}$ Also, Strachan et al were unable to observe a protective effect of reported infection on the development of atopy in the first month of life. ${ }^{8}$

\section{Antibiotic use}

Antibiotic treatment in the first two years of life predicted subsequent asthma, hay fever, and eczema (OR between 2.04 and 3.19 years).$^{70}$ In children with an anthroposophic lifestyle, Wickens et al found a higher risk of asthma when antibiotics were applied in infancy. ${ }^{71}$ Findings in German children also support the assumption of an increased risk of asthma in children treated with antibiotics early in life. ${ }^{79}$ In Australian children, Ponsonby et al did not find a difference in subsequent asthma or hay fever after antibiotic use. ${ }^{33}$

\section{Day care attendance}

Another specification of the hygiene hypothesis is exposure to other children in day care. Children attending day care had a higher frequency of infectious diseases ${ }^{80}$ Krämer et al suggested that early day care attendance (6-11 months) of children from small families in Germany (up to three individuals) was protective against allergic sensitisation and hay fever in children 5-14 years of age. ${ }^{61}$ This supposition was backed by findings in Arizona, US. Attendance at day care during the first six months of life reduced the relative risk of asthma $(R R=0.4$. $)$ Children with exposure to other children had more wheezing at the age of 2 years $(R R=1.4)$, but less wheezing from the age of 6 $(\mathrm{RR}=0.8)$ to the age of $13(\mathrm{RR}=0.3)$. Recently, Haby et al confirmed the protective effect of early attendance at day care for the risk of allergic sensitisation in Australian children $(n=650)$, but not for asthma, eczema, and hay fever. ${ }^{52}$ In children followed up since birth as part of the Tuscon Children's Respiratory Study, attendance at day care during the first six months of life protected against the development of asthma. ${ }^{34}$ Others were unable to observe a protective effect on the development of atopy resulting from exposure in infancy to children other than siblings. Findings by Pekkanen and coworkers in Finland (children 13-14 years of age) and by Nystad et al in Norway (children 6-16 years of age) do not support the day care hypothesis in children. Attending day care was associated with an increased risk of current symptoms of hay fever (OR $=1.2$ to 1.3). ${ }^{18} 81$ For children in New Zealand (7-9 years), day care attendance in the first year of life showed a non-significant increased relative risk of asthma $(\mathrm{OR}=1.81){ }^{71}$ In a cohort of 1369 persons born in Britain in 1958 and followed up to the age of 34-35 years, preschool nursery attendance did not protect against allergic sensitisation, ${ }^{48}$ nor did day care attendance in 
childhood in 13932 adults from Europe, New Zealand, and the United States. ${ }^{11}$ Additionally, although finding a protective effect, Haby et al could not support the infection hypothesis, as infections do not explain the protective effect of day care attendance..$^{52}$

\section{Childhood farm environment}

Following the infection hypothesis, studies were conducted comparing farm and urban environments. In children, farming as the parental occupation was significantly associated with lower rates of sneezing attacks, allergic sensitisation, wheezing, itchy skin rash and allergic rhinitis. ${ }^{82-84}$ Also in adults 18-24 years of age, childhood farm environment reduced the risk of allergic rhinitis. ${ }^{37}$ In other words, the old assumption that an urban environment might be a risk for atopic disease (pollution hypothesis, fig 5), ${ }^{85-89}$ was re-invented. However, the explanation changed from urban pollutants (automobile exhaust, etc) to protective factors typical for farm life. One speculation is that endotoxins from exposure to airborne bacterial products might enhance the Thl response pattern. ${ }^{90}$ However, this conclusion also might be premature, as other studies showed that in adults, farming is associated with exposures that increase wheezing and other respiratory responses. ${ }^{91}{ }^{92}$ In particular, endotoxin exposure in sawmill workers seems to contribute to respiratory problems. ${ }^{93}$

\section{Infections as risk factors for atopy}

Following an older school of thought, the bronchial susceptibility hypothesis (fig 5), respiratory infection might instigate changes that lead to asthma. In the mid-80s, a follow up study of 194 children in Massachusetts, US, suggested that respiratory illness in early life is associated with airway hyperresponsiveness as measured later in childhood. ${ }^{94}$ At the same time, a cross sectional study from Finland reported that children with infections in infancy had an increased prevalence of atopic manifestations. ${ }^{95}$ Recent studies showed that the risk of asthma was increased for children with lower respiratory tract infection, otitis media, whooping cough, mumps, and croup in the first year of life. ${ }^{70}{ }^{96}$ In particular, respiratory syncytical virus infections of the lower respiratory tract were associated with an increased risk of frequent wheezing by the age of 6 $(\mathrm{OR}=4.3)$, but not by the age of $13(\mathrm{OR}=1.4)$. There was no association between any history of lower respiratory tract infections and the subsequent point prevalence of allergic sensitisation. ${ }^{97}$ Thus, early childhood infections are expected to trigger or induce asthmatic symptoms in non-atopic children. In this subgroup, however, children with asthma symptoms seem to have a better prognosis than children with allergic sensitisation. ${ }^{79}$ Thus, the balance of evidence does not suggest that infection, other than by the faecal-oral route, is protective. Additionally, assuming that children who have a higher number of siblings are more likely to be exposed to a mixture of infections, including respiratory infections, it is questionable whether the number of infections plays a part in the sibling effect. Furthermore, in schoolchildren both forced vital capacity and forced expiratory volume were progressively larger with an increasing number of siblings. ${ }^{98}$ This finding is difficult to explain through increased exposure to respiratory infections with increasing number of siblings, particularly as pneumonia and bronchitis in the first years of life are associated with decreased lung function in later life. ${ }^{99}$

The contradictory features of the above findings indicate that the hygiene hypothesis failed to explain the findings adequately, or at least did not yet integrate essential and integrating explanations.

The contradictory features of the above findings, or at least did not yet integrate essential and integrating explanations.

\section{In utero and endocrine effects}

The in utero programming disruption hypothesis (fig 5) is a set of explanations on atopic manifestations to which little attention so far has been drawn. There is evidence to suggest that the maternal immune system during pregnancy can enhance or inhibit the development of the feto-placental unit. Recent data support the view that some cytokines produced by both $\mathrm{T}$ cells and non-T cells (IL3, GM-CSF, TGF $\beta$, IL4, IL10) favour fetal survival and growth. In contrast, other cytokines, such as IFN $\gamma$, TNF $\beta$ and TNF $\alpha$, can compromise pregnancy. Cytokines favouring the maintenance of fetal survival belong mainly to the Th2 pathway, whereas the failure of pregnancy is associated with the predominance of Thl type cytokines and/or the absence of Th2 type cytokines. This concept favours the importance of maternal immune suppression at the placental interface and the development of a Th2 response in the fetus as a consequence of maternal exposure to allergens. ${ }^{60}$

Another concept emphasises the role of hormones; progesterone and testosterone seem to promote the preferential development of Th2-like cells and induce transient IL4 production by established Thl cells, ${ }^{100-102}$ whereas relaxin, another corpus luteum derived hormone, mainly promotes the development of Thl-like cells. ${ }^{103}$ These findings could be linked to the fact that in childhood, asthma and allergic sensitisation are more prevalent in boys. ${ }^{2}$ Strachan showed that twins have statistically significantly fewer hospital admissions for asthma, but not for other causes of respiratory diseases, ${ }^{104}$ than singletons. Studies have indicated that the endocrine conditions are different in twin pregnancies, and that this affects other health outcomes. ${ }^{105}{ }^{106} \mathrm{~A}$ recent study indicated that the sibling effect is already manifested at birth. The concentration of cord blood IgE, a risk factor for subsequent atopic manifestations, ${ }^{107}$ decreased with age in children born on the Isle of Wight. ${ }^{108}$

Becklake et al reviewed the literature on gender differences and suggested that the airways in women are affected by hormonal regulation. ${ }^{109} \mathrm{Xu}$ et al reported from a Finnish investigation that maternal age at menarche influenced the prevalence of atopic manifestations in 31 year old offspring. Adult offspring are less likely to have allergic sensitisation (ascertained by SPT) if their mother reached menarche at a later age. ${ }^{110}$ Additionally, the use of contraceptives before pregnancy increased the risk of allergic disorders among children. ${ }^{111}$

These findings suggest some influence of the in utero environment (fig 5), which is likely to change with parity, as do some of the mother's lifestyle characteristics (employment, smoking, contact with other children). Also, change in maternal lifestyle is suggested to result in variations of cord blood IgE. ${ }^{112}$

Additionally, it is possible that endocrine disruptors such as organochlorines play a part (fig 5). Firstly, the organochlorine burden seems to decrease with birth order. ${ }^{113}{ }^{114}$ Secondly, placental organochlorine concentrations were related to cord blood IgE concentrations. ${ }^{115}$ And thirdly, some organochlorines seem to pose a risk for asthma and higher IgE levels. ${ }^{116}$

In conclusion, although the large body of evidence that incidence and prevalence of atopic eczema, asthma, hay fever, and allergic sensitisation are inversely related to the number of siblings, research has not yet answered the question: Which causal factors explain the sibling effect? Causal factors behind the sibling effect must meet two criteria; they must vary with sibship size and they must protect against atopic manifestations. The hygiene hypothesis might have misled research efforts. There is not sufficient covariation of infection and sibship size, $^{5270}$ and the association of markers of infections/ vaccinations, and atopic manifestation is not supported by sufficient evidence. It is time to consider alternative explanations such as in utero programming or endocrine effects. The epidemiology research into siblings and atopic disorders has entered an intellectually challenging phase. The proportion of cases attributable to the sibling effect is $34 \%$ for eczema, $28 \%$ for asthma, 56\% for hay fever, and 38\% for developing SPT/IgE. 
If we possessed knowledge about the causal factors behind the sibling effect, we might prevent at least $30 \%$ of all cases of asthma, eczema, and hay fever.

\section{ACKNOWLEDGEMENT}

The authors thank Linda Fortin for editorial support.

\section{Authors' affiliations}

W Karmaus, C Botezan, Department of Epidemiology, Michigan State University, USA

\section{REFERENCES}

1 Golding J, Peters T. Eczema and hay fever. In: Butler NR, Golding J, eds. From birth to five. a study of the health and behaviour of Britain's 5-year-olds. Oxford: Pergamon Press, 1986:171-86.

2 Kuehr J, Frischer T, Karmaus W, et al. Clinical atopy and associated factors in primary-school pupils. Allergy 1992;47:650-5.

3 Warner JO. Bronchial hyperresponsiveness, atopy, airway inflammation, and asthma. Pediatr Allergy Immunol 1998;9:56-60.

4 Schäfer T, Krämer U, Dockery D, et al. What makes a child allergic? Analysis of risk factors for allergic sensitization in preschool children from East and West Germany. Allergy and Asthma Proceedings 1999;20:23-7.

5 Strachan DP, Harkins LS, Golding J, et al. Sibship size and self-reported inhalant allergy among adult women. Clin Exp Allergy 1997;27:151-5.

6 Matricardi PM, Franzinelli F, Franco A, et al. Sibship size, birth order, and atopy in 11,371 Italian young men. J Allergy Clin Immunol 1998;101:439-44.

7 Strachan DP. Hay fever, hygiene, and household size. BM 1989;299: 1259-60

8 Strachan DP, Taylor EM, Carpenter RG. Family structure, neonatal infection, and hay fever in adolescence. Arch Dis Child 1996;74:422-6.

9 Mattes J, Karmaus W, Moseler M, et al. Accumulation of atopic disorders within families: a sibship effect only in the offspring of atopic fathers. Clin Exp Allergy 1998;28:1480-6.

10 Sunyer J, Antó JM, Kogevinas $M$, et al. Risk factors for asthma in young adults. Spanish Group of the European Community Respiratory Health Survey. Eur Respir J 1997; 10:2490-4.

11 Svanes C, Jarvis D, Chinn S, et al. Childhood environment and adult atopy: results from the European Community Respiratory Health Survey. J Allergy Clin Immunol1999:103:415-20.

12 Bodner C, Godden D, Seaton A. Family size, childhood infections and atopic diseases. The Áberdeen WHEASE Group. Thorax 1998;53:28-32.

13 Christie GL, McDougall CM, Helms PJ. Is the increase in asthma prevalence occurring in children without a family history of atopy? Scott Med J 1998;43:180-2.

14 Butland BK, Strachan DP, Lewis S, et al. Investigation into the increase in hay fever and eczema at age 16 observed between the 1958 and 1970 British birth cohorts. BM 1997;315:717-21.

15 Olesen $\mathbf{A B}$, Ellingsen AR, Larsen FS, et al. Atopic dermatitis may be linked to whether a child is first- or second-born and/or the age of the mother. Acta Derm Venereol 1996;76:457-60.

16 Ponsonby AL, Couper D, Dwyer T, et al. Cross sectional study of the relation between sibling number and asthma, hay fever, and eczema. Arch Dis Child 1998;79:328-33.

17 Lewis SA, Britton JR. Consistent effects of high socioeconomic status and low birth order, and the modifying effect of maternal smoking on the risk of allergic disease during childhood. Respir Med 1998;92:1237-44.

18 Pekkanen J, Remes S, Kajosaari M, et al. Infections in early childhood and risk of atopic disease. Acta Paediatr 1999:88:710-14.

19 Taylor B, Wadsworth J, Golding J, et al. Breast feeding, eczema, asthma, and hayfever. J Epidemiol Community Health 1983;37:95-9.

20 Bennis A, el Fassy Fihry MT, Fikri-Benbrahim N, et al. The prevalence of adolescent asthma in Rabat. A survey conducted in secondary schools. Rev Mal Respir 1992;9:163-9.

21 Crane J, Pearce N, Shaw R, et al. Asthma and having siblings. [letter; comment].BM 1994;309:272

22 Shaw R, Woodman K, Crane J, et al. Risk factors for asthma symptoms in Kawerau children. N Z Med J 1994;107:387-91.

23 Lewis S, Richards D, Bynner J, et al. Prospective study of risk factors for early and persistent wheezing in childhood. Eur Respir J 1995;8:349-56

24 Moyes CD, Waldon J, Ramadas D, et al. Respiratory symptoms and environmental factors in schoolchildren in the Bay of Plenty. N Z Med J 1995; 108:358-61.

25 Stoddard JJ, Miller T. Impact of parental smoking on the prevalence of wheezing respiratory illness in children. Am J Epidemiol 1995;141:96-102

26 Jarvis D, Chinn S, Luczynska C, et al. The association of family size with atopy and atopic disease. Clin Exp Allergy 1997;27:240-5.

27 Rona RJ, Duran-Tauleria E, et al. Family size, atopic disorders in parents, asthma in children, and ethnicity. J Allergy Clin Immuno 1997:99:454-60.

28 Attena F, Agozzino E, Toscano G, et al. Prevalence of asthma among young men in a military recruitment office of South Italy. Eur J Epidemiol 1999;15:569-72.
29 Leadbitter P, Pearce N, Cheng S, et al. Relationship between fetal growth and the development of asthma and atopy in childhood. Thorax 1999;54:905-10.

30 Rona RJ, Hughes JM, Chinn S. Association between asthma and family size between 1977 and 1994. J Epidemiol Community Health 1999:53:15-19.

31 Wickens KL, Crane J, Kemp TJ, et al. Family size, infections, and asthma prevalence in New Zealand children. Epidemiology 1999;10:699-705.

32 Xu X, Yang J, Chen C, et al. Familial aggregation of pulmonary function in a rural Chinese community. Am J Respir Crit Care Med1999:160:1928-33.

33 Ponsonby AL, Couper D, Dwyer T, et al. Relationship between early life respiratory illness, family size over time, and the development of asthma and hay fever: a seven year follow up study. Thorax 1999;54:664-9.

34 Ball TM, Castro-Rodriguez JA, Griffith KA, et al. Siblings, day-care attendance, and the risk of asthma and wheezing during childhood. $N$ Engl J Med 2000;343:538-43

35 Bodner C, Anderson WJ, Reid TS, et al. Childhood exposure to infection and risk of adult onset wheeze and atopy. Thorax 2000;55:383-7.

36 Rasanen M, Kaprio J, Laitinen T, et al. Perinatal risk factors for asthma in Finnish adolescent twins. Thorax 2000;55:25-31.

37 Kilpelainen $\mathbf{M}$, Terho EO, Helenius $\mathrm{H}$, et al. Farm environment in childhood prevents the development of allergies. Clin Exp Allergy2000;30:201-8.

38 Bråbäck L, Hedberg A. Perinatal risk factors for atopic disease in conscripts. Clin Exp Allergy 1998;28:936-42.

39 Rasanen M, Laitinen T, Kaprio J, et al. Hay fever, asthma and number of older siblings-a twin study. Clin Exp Allergy 1997;27:515-18.

40 Davis JB, Bulpitt CJ. Atopy and wheeze in children according to parental atopy and family size. Thorax 1981;36:185-9.

41 Weitzman M, Gortmaker S, Sobol A. Racial, social, and environmental risks for childhood asthma. American Journal of Diseases of Children 1990; 144: 1 189-94.

42 Strachan DP. Epidemiology of hay fever: towards a community diagnosis. Clin Exp Allergy 1995;25:296-303.

43 Lewis SA, Britton JR. Measles infection, measles vaccination and the effect of birth order in the aetiology of hay fever. Clin Exp Allergy 1998;28: 1493-500.

44 von Mutius E, Martinez FD, Fritzsch C, et al. Skin test reactivity and number of siblings. BM 1994;308:692-5.

45 Bråbäck L, Breborowicz A, Julge K, et al. Risk factors for respiratory symptoms and atopic sensitisation in the Baltic area. Arch Dis Child 1995; 72:487-93

46 Nowak D, Heinrich J, Jörres R, et al. Prevalence of respiratory symptoms, bronchial hyperresponsiveness and atopy among adults: West and East Germany. Eur Respir J 1996;9:2541-52.

47 Burr ML, Merrett TG, Dunstan FD, et al. The development of allergy in high-risk children. Clin Exp Allergy 1997;27:1247-53.

48 Strachan DP, Harkins LS, Johnston ID, et al. Childhood antecedents of allergic sensitization in young British adults. J Allergy Clin Immunol 1997;99:6-12

49 Forastiere F, Agabiti N, Corbo GM, et al. Socioeconomic status, number of siblings, and respiratory infections in early life as determinants of atopy in children. Epidemiology 1997;8:566-70.

50 Matricardi PM, Rosmini F, Ferrigno L, et al. Cross sectional retrospective study of prevalence of atopy among Italian military students with antibodies against hepatitis A virus. BN 1997;314:999-1003.

51 Storm van's Gravensande K, Karmaus W, et al. Mutterliches alter und anzahl der geschwister. Monatsschrift Kinderheilkunde 1998; 146:471-5

52 Haby MM, Marks GB, Peat JK, et al. Daycare attendance before the age of two protects against atopy in preschool age children. [In Process Citation]. Pediatr Pulmonol 2000;30:377-84

53 Tariq SM, Matthews SM, Hakim EA, et al. The prevalence of and risk factors for atopy in early childhood: a whole population birth cohort study. J Allergy Clin Immunol 1998;101:587-93.

54 Kuehr J, Karmaus W, Frischer T, et al. Longitudinal variability of skin prick test results. Clin Exp Allergy 1992;22:839-44.

55 Strachan DP. Family size, infection and atopy: the first decade of the hygiene hypothesis. Thorax 2000;55:S2-10.

56 Infante-Rivard C, Amre D, Gautrin D, et al. Family size, day-care attendance, and breastfeeding in relation to the incidence of childhood asthma. Am J Epidemiol 2001;153:653-8.

57 Mosmann TR, Sad S. The expanding universe of T-cell subsets: Th1, Th2 and more. Immunol Today 1996;17:138-46.

58 Erb KJ. Atopic disorders: a default pathway in the absence of infection? Immunol Today 1999;20:317-22.

59 Holt PG. Programming for responsiveness to environmental antigens that trigger allergic respiratory disease in adulthood is initiated during the perinatal period. Environ Health Perspect 1998;3:795-800.

60 Warner JA, Jones AC, Miles EA, et al. Maternofetal interaction and allergy. Allergy 1996;51:447-51.

61 Krämer U, Heinrich J, Wist $M$, et al. Age of entry to day nursery and allergy in later childhood. Lancet 1999;353:450-4.

62 Matricardi M, Rosmini F, Rapicetta M, et al. Atopy, hygiene, and lifestyle. Lancet 1999:354:430.

63 Martinez FD. Role of respiratory infection in onset of asthma and chronic obstructive pulmonary disease. Clin Exp Allergy 1999;29:53-8.

64 Aberer W, Geusau A, Pirkhammer D, et al. Epidemiology and diagnosi of allergic diseases. Wien Klin Wochenschr 1993;105:624-7.

65 Carey OJ, Cookson JB, Britton J, et al. The effect of lifestyle on wheeze, atopy, and bronchial hyperreactivity in Asian and white children. Am J Respir Crit Care Med 1996;154:537-40. 
66 Pin I, Pilenko-McGuigan C, Cans C, et al. Epidemiology of respiratory allergy in children. Arch Pediatr 1999;6:6-13S.

67 Alm JS, Swartz J, Lilja G, et al. Atopy in children of families with an anthroposophic lifestyle. Lancet 1999;353:1485-8.

68 Shaheen SO, Aaby P, Hall AJ, et al. Measles and atopy in Guinea-Bissau. Lancet 1996;347:1792-6.

69 Kemp T, Pearce N, Fitzharris $P$, et al. Is infant immunization a risk factor for childhood asthma or allergy? Epidemiology 1997;8:678-80.

70 Farooqi IS, Hopkin JM. Early childhood infection and atopic disorder. Thorax 1998:53:927-32

71 Wickens K, Pearce N, Crane J, et al. Antibiotic use in early childhood and the development of asthma. Clin Exp Allergy 1999;29:766-71.

72 Henderson J, North K, Griffiths M, et al. Pertussis vaccination and wheezing illnesses in young children: prospective cohort study. The Longitudinal Study of Pregnancy and Childhood Team. BM 1999;318:1173-6

73 Shirakawa T, Enomoto T, Shimazu S, et al. The inverse association between tuberculin responses and atopic disorder. Science 1997;275:77-9.

74 Aaby $\mathbf{P}$, Shaheen SO, Heyes CB, et al. Early BCG vaccination and reduction in atopy in Guinea-Bissau. Clin Exp Allergy 2000;30:644-50.

75 Strannegard IL, Larsson LO, Wennergren G, et al. Prevalence of allergy in children in relation to prior BCG vaccination and infection with atypical mycobacteria. Allergy 1998;53:249-54.

76 Omenaas $\mathbf{E}$, Jentoft HF, Vollmer WM, et al. Absence of relationship between tuberculin reactivity and atopy in BCG vaccinated young adults. Thorax 2000;55:454-8.

77 von Mutius E, Pearce N, Beasley R, et al. International patterns of tuberculosis and the prevalence of symptoms of asthma, rhinitis, and eczema. Thorax 2000;55:449-53.

78 Matricardi PM, Rosmini F, Riondino S, et al. Exposure to foodborne and orofecal microbes versus airborne viruses in relation to atopy and allergic asthma: epidemiological study. BM 2000;320:412-17.

79 von Mutius E, Illi S, Hirsch T, et al. Frequency of infections and risk of asthma, atopy and airway hyperresponsiveness in children. Eur Respir J 1999;14:4-11.

80 Celedon JC, Litonjua AA, Weiss ST, et al. Day care attendance in the first year of life and illnesses of the upper and lower respiratory tract in children with a familial history of atopy. Pediatrics 1999;104:495-500.

81 Nystad W, Skrondal A, Magnus P. Day care attendance, recurrent respiratory tract infections and asthma. Int J Epidemiol 1999;28:882-7.

82 Braun-Fahrlander C, Gassner M, Grize L, et al. Prevalence of hay fever and allergic sensitization in farmer's children and their peers living in the same rural community. SCARPOL team. Swiss Study on Childhood Allergy and Respiratory Symptoms with Respect to Air Pollution. Clin Exp Allergy 1999;29:28-34

83 Von Ehrenstein OS, Von Mutius E, Illi S, et al. Reduced risk of hay fever and asthma among children of farmers. Clin Exp Allergy 2000;30:187-93.

84 Riedler J, Eder W, Oberfeld G, et al. Austrian children living on a farm have less hay fever, asthma and allergic sensitization. Clin Exp Allergy2000;30: 194-200.

85 Kerrebijn KF, Mourmans AR. Study on the relationship of air pollution to respiratory disease in schoolchildren. Environ Res 1975;10:14-28.

86 Levy D, Gent M, Newhouse MT. Relationship between acute respiratory illness and air pollution levels in an industrial city. American Review of Respiratory Disease 1977;116:167-73.

87 Ribon A, Perera S, Gavencak J. Air pollution: its effects on health and respiratory disease-a review. Ann Allergy 1977;39:279-83.

88 Gaudio SA. Air pollution and its effects on adult asthmatics: a review. Mt Sinai J Med 1980;47:329-34.

89 Nilsson L, Castor O, Lofman O, et al. Allergic disease in teenagers in relation to urban or rural residence at various stages of childhood. Allergy 1999:54:716-21.

90 Martinez FD, Holt PG. Role of microbial burden in aetiology of allergy and asthma. Lancet 1999;354:SII12-15.

91 Vogelzang PF, van der Gulden JW, Folgering $\mathrm{H}$, et al. Longitudinal changes in bronchial responsiveness associated with swine confinement dust exposure. Chest 2000;117:1488-95.
92 Sprince NL, Lewis $M Q$, Whitten PS, et al. Respiratory symptoms: associations with pesticides, silos, and animal confinement in the lowa Farm Family Health and Hazard Surveillance Project. Am J Ind Med 2000;38:455-62

93 Douwes J, Mclean D, van der Maarl E, et al. Worker exposures to airborne dust, endotoxin and beta(1,3)-glucan in two New Zealand sawmills. Am J Ind Med 2000;38:426-30.

94 Weiss ST, Tager IB, Muñoz A, et al. The relationship of respiratory infections in early childhood to the occurrence of increased levels of bronchial responsiveness and atopy. American Review of Respiratory Disease 1985;131:573-8

95 Backman A, Bjorksten F, Ilmonen S, et al. Do infections in infancy affect sensitization to airborne allergens and development of atopic disease? $A$ retrospective study of seven-year-old children. Allergy 1984;39:309-15.

96 Nafstad P, Magnus P, Jaakkola JJ. Early respiratory infections and childhood asthma. Pediatrics 2000;106:E38.

97 Stein RT, Sherrill D, Morgan WJ, et al. Respiratory syncytial virus in early life and risk of wheeze and allergy by age 13 years. Lancet 1999;354:541-5.

98 Mattes J, Karmaus W, Storm van's Gravesande K, et al. Pulmonary function in children of school age is related to the number of siblings in their family. Pediatr Pulmonol 1999:28:414-17.

99 Shaheen SO, Sterne JA, Florey CD. Birth weight, childhood lower respiratory tract infection, and adult lung function. Thorax 1998;53:549-53.

100 Piccinni MP, Giudizi MG, Biagiotti R, et al. Progesterone favors the development of human $T$ helper cells producing Th2-type cytokines and promotes both IL- 4 production and membrane CD30 expression in established Th 1 cell clones. J Immunol 1995;155:128-33.

101 Szekeres-Bartho J, Wegmann TG. A progesterone-dependent immunomodulatory protein alters the Th1/Th2 balance. J Reprod Immunol 1996;31:81-95.

102 Whitacre CC, Reingold SC, O'Looney PA. A gender gap in autoimmunity. Science 1999;283:1277-8.

103 Piccinni MP, Bani D, Beloni L, et al. Relaxin favors the development of activated human T cells into Th1-like effectors. Eur J Immunol 1999;29:2241-7.

104 Strachan DP, Moran SE, Mclnneny K, et al. Reduced risk of hospital admission for childhood asthma among Scottish twins: record linkage study. BM 2000;321:732-3.

105 Kaprio J, Rimpela A, Winter T, et al. Common genetic influences on BMI and age at menarche. Hum Biol 1995;67:739-53.

106 Kaijser M, Lichtenstein P, Granath F, et al. In utero exposures and breast cancer: a study of opposite-sexed twins. J Natl Cancer Inst 2001;93:60-2

107 Orgel HA, Hamburger RN, Bazaral M, et al. Development of lgE and allergy in infancy. J Allergy Clin Immunol 1975:56:296-307.

108 Karmaus W, Arshad H, Mattes J. The sibling effect may have its origin in utero. An investigation into birth order, cord-blood lgE concentration, and allergic sensitization at age four. Am J Epidemiol 2001;154:909-15

109 Becklake MR, Kauffmann F. Gender differences in airway behaviour over the human life span. Thorax 1999:54:1119-38.

$110 \mathrm{Xu}$ B, Jarvelin MR, Hartikainen AL, et al. Maternal age at menarche and atopy among offspring at the age of 31 years. Thorax 2000;55:691-3.

111 Xu B, Jarvelin MR, Pekkanen J. Prenatal factors and occurrence of rhinitis and eczema among offspring. Allergy 1999;54:829-36.

112 Shirakawa T, Morimoto K, Sasaki S, et al. Effect of maternal lifestyle on cord blood lgE factor. Eur J Epidemiol 1997:13:395-402.

113 Vaz R, Slorach SA, Hofvander Y. Organochlorine contaminants in Swedish human milk: studies conducted at the National Food Administration 1981-1990. Food Addit Contam 1993;10:407-18.

114 Schade G, Heinzow B. Organochlorine pesticides and polychlorinated biphenyls in human milk of mothers living in northern Germany: current extent of contamination, time trend from 1986 to 1997 and factors that influence the levels of contamination. Sci Total Environ 1998:215:31-9.

115 Reichrtova E, Ciznar P, Prachar V, et al. Cord serum immunoglobulin E related to environmental contamination of human placentas with organochlorine compounds. Environ Health Perspect 1999;107:895-9.

116 Karmaus W, Kuehr J, Kruse H. The prevalence of infections and atopic manifestations in childhood might be related to the blood concentration of organochlorine compounds. Arch Environ Health (in press). 